\title{
CONTINENTAL DRIFT, MESOZOIC CONTINENTS AND THE MIGRATIONS OF THE ANGIOSPERMS
}

\author{
By DR. R. MELVILLE \\ Royal Botanic Gardens, Kew
}

THE origin of the flowering plants, how they came to appear relatively suddenly in the northern hemisphere in the Cretaceous and how they attained their present distribution are different aspects of one of the outstanding problems of biology. In recent decades it has become increasingly evident that the angiosperms must have had a long evolutionary history before the Cretaceous. Hawkes and Smith $^{1}$ recently supplied evidence favouring the existence of the genera Gossypium, Bromus and Solanum early in the Cretaceous and suggested an origin much earlier and probably on the former continent of Gondwanaland. Stebbins ${ }^{2}$, Thomas ${ }^{3}$ and Camp ${ }^{4}$ have reached similar conclusions from studies of living angiosperms, and Plumstead ${ }^{5}$ has reviewed the fossil Glossopteridae, which dominated the flora of Gondwanaland, and discussed the evidence linking them with the angiosperms. In evidence drawn mainly from floral vascular systems, I have proposed ${ }^{6-8}$ a new theory of floral evolution, which indicated the Glossopteridae as the probable ancestral group of the angiosperms. The problem is too complex to be solved by any single line of evidence, but requires the correlation of data from many fields including taxonomy, phylogeny, palaeobotany, palaeogeography, geomorphology and palaeomagnetism.

The critical period for this study extends through the Jurassic and Cretaceous when Mesozoic land masses were breaking up before their rearrangement into the present continental system. Before this upheaval, during the Palaeozoic and the early part of the Mesozoic, four great floral regions can be distinguished. Three of these were in the northern hemisphere and the fourth occupied the former Gondwana continent, which endured in the south from about the Silurian until it began to break up in the Jurassic. Palaeobotanical evidence does not indicate any contact between Gondwanaland and the northern continents during the whole of this long period ${ }^{5,9}$. Recent palaeomagnetic research has provided independent evidence for the continued existence of the Gondwana continent at this time ${ }^{10}$.

By the Carboniferous, the Glossopteridae had developed as the characteristic flora of Gondwanaland. In the northern hemisphere, the coal flora occupied western Europe and eastern North America, which together formed a continent centred over the North Atlantic, which may be called Atlantica. A second distinctive flora, the Gigantopteris or Cathaysian flora, occupied a large part of China and South-east Asia and also the western part of North Amorica ${ }^{9}$. These regions formed a continent centred over the North Pacific which may be called 'Pacifica'. In the region between, the Angara flora occupied an area covering Siberia southwards to about the present $40^{\circ}$ parallel of latitude. At a later epoch the orogenesis which split up and dispersed Gondwanaland also cleft in two both Atlantica and Pacifica. Western Atlantica drifted into contact with Eastern Pacifica to form the present North American continent. The other two fragments, Eastern Atlantica and Western Pacifica, contributed to the modern Eurasiatic landmass. We must now seek evidence for the boundaries of these ancient continents and their positions at the beginning of the orogenesis.

Geological discontinuities along the sites of ancient geosynclines mark the boundaries of the former continental fragments, which came together to make the present continents. The distribution of earlier floras can be traced from the fossil record and can be correlated with the geological evidence to make a reconstruction of the former continents before their rearrangement. Following this line of research, we find that fossil Glossopteridae occur in South America only south of the Amazon, so that only the southern portion can have formed part of Gondwanaland. The Amazon itself is no ordinary river. Although it runs for more than 2,000 miles through country not more than $36 \mathrm{ft}$. above sea-level its channel is broad and deep. At 500 miles above Para the river is still $348 \mathrm{ft}$. deep ${ }^{11}$. These unusual features can be accounted for if the river follows a rift where continental blocks came together.

Crossing the Atlantic to the African shore, a deep trench is found in the seabed in latitude $8-9^{\circ}$ N. off Sierra Leone $^{12}$. This probably marks the junction between the north-west portion of Africa, which yields no Glossopteris fossils, and the remainder of the continent which formed part of Gondwanaland. From $10^{\circ} \mathrm{N}$. on the coast, the boundary of the old Gondwana block skirts around the uplands of Futa Jalon and then follows roughly the line of the Niger to Timbuktu. Thence it runs northwards to skirt around the Ahaggar massif and follows the line of the high ground around to the mouth of the Nile. Arabia belongs with Africa to Gondwanaland, and the boundary then follows the coast of the Mediterranean to the head of the Gulf of Iskenderun. From this point it turns eastwards, following the southern boundary of the Anatolian Mountains and finally south-eastwards along the edge of the Zagros Mountains to the Persian Gulf.

Passing eastwards, India forms the next Gondwanic block. The boundary of the Glossopteris flora has been discussed by Sahni ${ }^{13}$. From Karachi it follows the valley of the Indus to the Himalaya, then along the line of the Himalaya to about long. $100^{\circ}$ E., lat. $30^{\circ} \mathrm{N}$. From this point it turns southwards along the line of the ranges between the Salween and Mekong rivers to Malaya. Sahni took the boundary along the spine of Malaya, but was uncertain whether or not to include Borneo as part of Gondwanaland. Some fossil Glossopteridae have been found in Borneo ${ }^{9}$ which forms part of the Oriental faunal region ${ }^{14}$. The Wallace line, which passes along the Makasar Strait between Borneo and Celebes and through the deep strait between Bali and Lombok, marks the boundary of two distinctive faunal provinces. From what follows in this article, it is probable that it also is part of a Gondwanic boundary, the islands to the west, Sumatra, Java, Bali and Borneo, with the whole of Malaya forming part of the Indian block of the Gondwana continent.

The whole of the Australian continent belongs without question to Gondwanaland, but doubt remains about 
New Guinea. The similarities between the floras are too slight for New Guinea to have been associated with Australia for a long period, as pointed out by Good ${ }^{15}$. It has been excluded in the present reconstruction except for the Merauke Ridge. The presence of the Upper Gondwana flora in New Zealand indicates its origin and with it must go the extensive ramified block on which it stands, the greater part of which is now submerged. The associated islands include New Caledonia, Fiji and Samoa, and to the south, Macquarie and Campbell. Finally, the whole of Antarctica belongs to Gondwanaland; fossil Glossopteridae are known from both east and west provinces ${ }^{5}$.

The present positions of the fragments of Gondwanaland are shown in Fig. 1. Because the boundary line has been determined primarily from the distribution of the Glossopteridae, it will be convenient to call it the 'Glossopterid Lino'. The general trend of this line is confirmed by the distribution of other fossil and modern gymnosperms. Florin $^{\mathbf{1 6}}$ has established that different groups of gymnosperms occupied the northern and the southern (Gondwana) continents in the Palaeozoic and Mesozoic up to the end of the Jurassic. Taking Podocarpus as an example of the southern group, all its fossils are south of the line, and the living species only transgress the line in SouthEast Asia and in the North Amazonian province of South America and Central America, where they have migrated since the beginning of the Cretaceous. Conversely, fossil pines (Pinus) are only known north of the line and the modern species only cross the line into Syria, and small areas in Burma and Sumatra.

Any reconstruction of the Gondwana continent should take into account the physiography of the ocean basins and palaeomagnetic and biological data. In the solution offered by King and Downard ${ }^{17}$. India is not in a position consistent with drift along the line of the two great transcurrent faults of the Maldive-Laccadive and Ninety-East degree. They also place the New Zealand block in contact with Eastern Australia, a position inconsistent with the absence of the large Australian genera Eucalyptus and Acacia from New Zealand. Creer's partial reconstruction ${ }^{10}$ based on palaeomagnetic data also requires adjustment in the light of other evidence, while that of Ahmad18 conflicts with the position of ocean rises and the Carboniferous glaciation. The mid-oceanic rises may be used as the starting-points for the reassembly of the dispersed fragments. The Gondwanic portions of Africa and South America can be fitted along the South Atlantic Rise in the positions worked out by Bullard et al.18a. The position of the combined block must have been somewhat to the south before the break-up of Gondwanaland and in contact with Antarctica. Menard's map of the Pacific basin $^{20}$ shows some remarkable coincidences between the shape of the submerged continental platform of east Antarctica and that of the Pacific-Antarctic Rise, which fixes a position for Antarctica. This would bring the coast east of the Weddell Sea in contact with Africa. The Malaysian part of the Indian block must have been in contact with peninsular India. The two parts fit together along the Ninety-East fault if the Malayan peninsula is flexed at its narrowest point to straighten it. By moving the Indian block so assembled southwards along the Ninety Degree and Maldive-Laccadive faults, it fits into the arc of the South Indian Rise in proximity to the new position of Antaretica. No palaeomagnetic data are available to check the position of India, but Irving and Green $^{21}$ have given a pole position for the older volcanics of Victoria, estimated to be of older Pliocene age, which would bring that part of Australia over the IndianAntarctic Rise and considerably to the west of its present position. For this to be possible in relation to the remaining parts of Gondwanaland, Australia would need to be rotated through a right angle into the position shown in Fig. 2. This would imply very little change in latitude for Western Australia since the Jurassic, but considerable changes in latitude and climate for Eastern Australia. Such a sequence of events is consistent with the high proportion of endemies in the Western Australian flora and the survival of many relatively primitive forms in that area. Finally, the New Zealand block must have been to the south-east along the Pacific Antarctic Rise opposite Eastern Antarctica. Palaeomagnetic evidence is unfortunately wanting for this area.

The extent and direction of the Carboniferous glaciation as recorded by Holmes ${ }^{22}$ may be used as an independent check on the validity of the reconstruction. With the proposed assembly the glaciated area would be nearly circular and the directions of the ice flow (Fig. 2) are in good agreement. The positions for Creer's South American poles 14 and 15 (ref. 10) lie close to the apparent geographical pole and are consistent with the reconstruction.

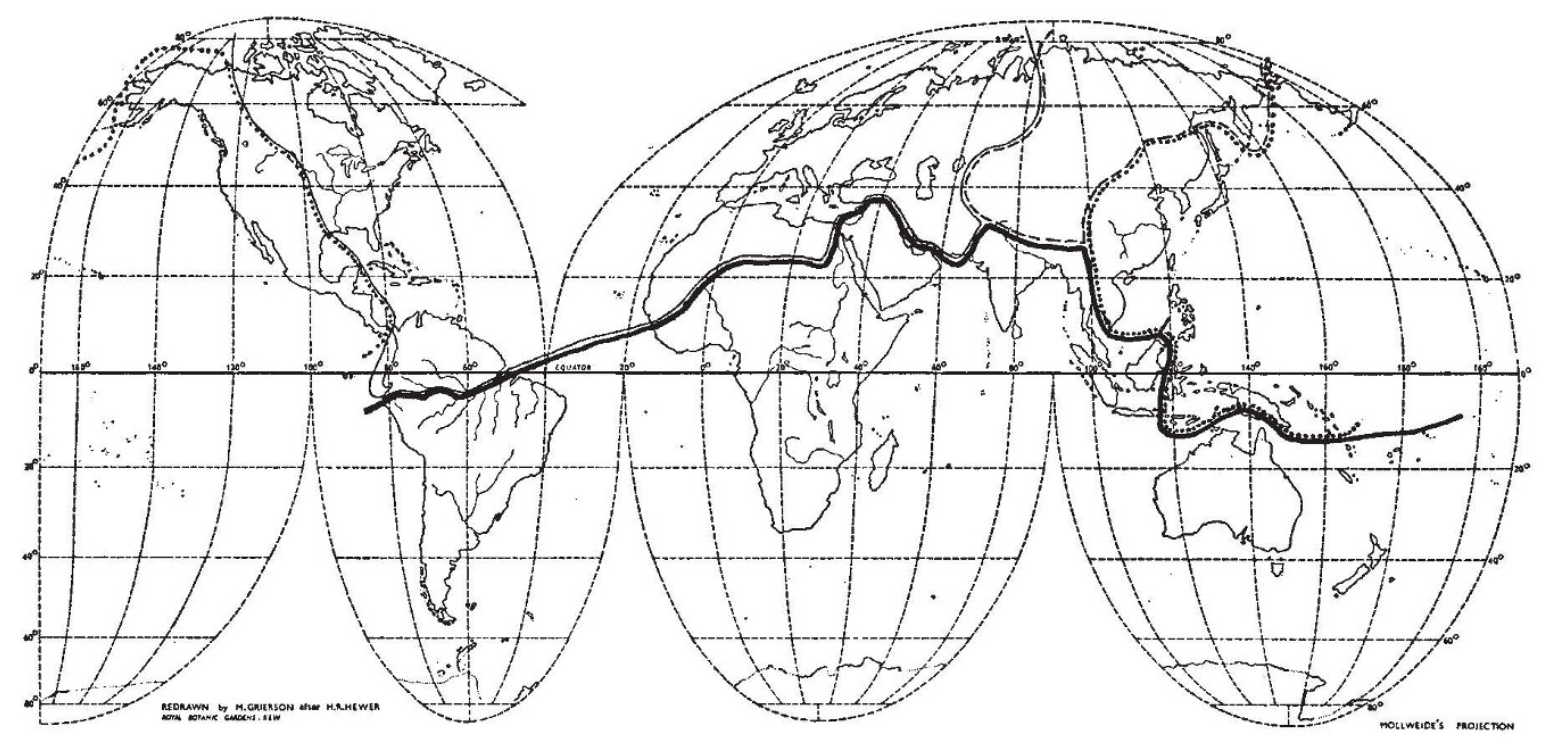

Fig. L. Palaeozoic floral regions. Heavy line, the glossopterid line marking the northern boundary of the fragments of Gondwanaland; thin line, boundary of the Carboniferous coal flora; dotted line, boundary of the Gigantopteris flora; broken line, boundary of the Angara flora 


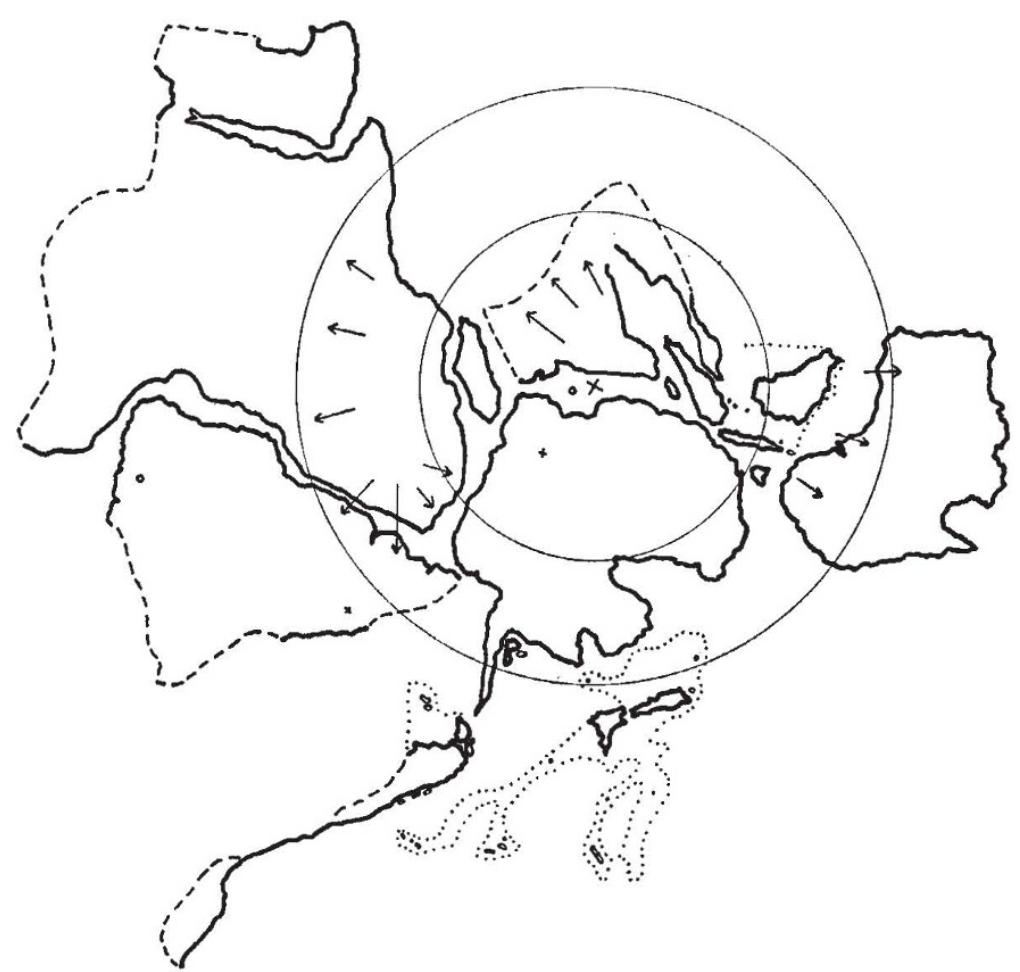

Fig. 2. Reconstruction of Gondwanaland. The approximate Carboniferous geographical south pole is marked, with the Antaretic circle and $50^{\circ}$ eircle of latitude which nearly coincides with the limits of the Carboniferous glaciation in South America, Africa, and Australia. Creer's South American palaeomagnetic poles Nos. 14 and 15 are shown with their conjugate points. Dotted lines, continental shelves; broken lines, severed continental boundaries; arrows, direction of Carboniferous iceflow

Atlantica in the position shown in Bullard's reconstruction. A large bay then separated south-west Atlantica from South America, the eastern end of which is shown in Bullard's reconstruction as an anomalous triangular gap.

Little attention has been given to the possibility of a mid-Pacific continent in the Mesozoic, but the evidence for the existence of Pacifica is of the same kind as that for Atlantica. In both cases the present oceans are flanked by continents bearing the severed halves of a Palaeozoic flora-respectively the Gigantopteris and the coal floras. In both there is a midocean rise which marks the line of the upwelling convection current that caused the severance of the former continents, that for the Pacific being called the Darwin Rise by Menard ${ }^{20}$ to distinguish it from the East Pacific Rise. Over the significant areas of both oceans no fossils or datable material of pre-Cretaceous age have been found ${ }^{18 b}, 20$. Much evidence from geological coincidences ${ }^{18 d}$ and palaeomagnetic measurements ${ }^{19 c}$ supports continental drift in the Atlantic. The evidence for the Pacific is much less complete, primarily because far less attention has been given to it.

Two periods of regional metamorphosis are reported for $\operatorname{Japan}^{19 e}, 200$ and 100 million years ago, which would correspond with block faulting in the Permian and later volcanism accompanying drift in the Cretaceous. Western North America was geosynclinal in the late

Turning now to the northern hemisphere, the fit of the two sides of the North Atlantic as calculated by Bullard ${ }^{19 a}$ can be accepted, except that further consideration must be given to the non-Gondwanic portions of Africa and South America. There is reason to think that north-west Africa formed part of Atlantica, as Wilson ${ }^{19_{b}}$ has directed attention to the fact that Hercynian fold belts of this region complete the southern part of the Newfoundland - Virginia belt of the same age. No such guide is avail. able for the north Amazonian block of South America. Palaeomagnetic data are lacking for both areas. No fit can be made between the Caribbean shores of the Americas as they exist at present. Before the reconstruction of Atlantica can be attempted the part of North America which before the Jurassic formed part of Pacifica must be removed. The boundary as indicated by fossils of the Gigantopteris flora ${ }^{9}$ runs southwards from the mouth of the Mackenzie River skirting east of the Rockies to a point on the Gulf of Mexico west of the Mississippi delta (Fig. 1). The presence of marine deposits of Permian to Jurassic age in the Mackenzie basin is consistent with this boundary ${ }^{10 b}$, which is confirmed by Schuchert's palaeogeographic maps for these periods ${ }^{23}$. The low-lying Florida peninsula formed of Cretaceous and later sediments did not exist at tho period with which we are concerned. Jurassic seas pierced the contral American isthmus in two places and an arm of the Jurassic sea must have penetrated as far as the Cape Verde Islands to account for the only marine Jurassic deposit along the whole of the Atlantic ${ }^{19 b}$. Probably block faulting across the south-western part of Atlantica was responsible for these effects, separating the Greater Antilles, which can be fitted neatly along the northern coast of South America. If, now, the North Amazonian block is moved into position against North America, Atlantica will be complete.

By the end of the Jurassic the South America-African block must have drifted into contact with south-eastern
Mesozoic ${ }^{19 f}$ when drift was closing the gap between the western and eastern parts of the continent. Palaeomagnetic results for western North America are discordant with those from the east and indicate a former separation. No palaeomagnetic data for the Mesozoic of China have come to my notice, but the poles calculated by Deutsch and Watkins ${ }^{24}$ for the Triassic of the Tunguska River region of Siberia indicate a position of the Angara block $25^{\circ}$ south and $87^{\circ}$ to the east of its present position. For this to be true, the Angara block must have been in contact with Cathaysia at that time, when the present coast of China was in the middle of the Pacific. The augmented Pacific continent must have been in existence at least from the Triassic until it broke up early in the Cretaceous, but the Cathaysian core extended back to the Carboniferous.

An attempt can now be made to reconstruct Pacifica. The fragments can be assembled along the line of the Darwin Rise in its present position. No difficulty arises in placing the western American portion, but the island arcs off the eastern coast of Asia must be closed up to form a compact mass against the continental shelves. In Fig. 3, the deeps of the enclosed seas of Okhotsk, Japan, and East and South China are eliminated and the peninsulas of Kamchatka and Korea have been folded against the continental margin; Borneo and the parts of Malaysia which do not form part of Cathaysia have been removed. New Guinea, which floristically and geologically is distinct from Australia ${ }^{15}$, has been placed in a position to fit the curvature of the Darwin Rise, and so complete the continent.

From the Jurassic to the Cretaceous another land mass existed in the South Pacific. This consisted of the New Zealand block together with Antarctica assembled along the line of the South-east Pacific Rise in the position already indicated for the reconstruction of Gondwanaland. In addition, it is probable that the Andean provinces of South America, embracing Peru, Bolivia, Chile and Western Argentina, south of the Gulf of San Jorge with 
Fuegia and the Falklands, were situated along the eastern edge of the rise. The eastern boundaries of these provinces are marked by a line of marine Jurassic sediments ${ }^{25}$. Allowance has been made in the reconstruction for the displaced section of the rise south of the Easter Island fault. Palaeomagnetic data are wanting for this South Pacific continent, but it is supported by the distribution of numerous plant genera and species and by the absence of Carboniferous glaciation in Patagonia.

For the biologist, the timing of the various episodes in the break-up of the Mesozoic continents is of the utmost importance. The moment of severance limits the migration of land organisms by normal methods and must be a major factor in determining modern distributions. Evidence for stages in the break-up of Atlantica is more complete than for any other continent. The initial faulting which demarcated Greenland occurred in the Carboniferous ${ }^{19 \theta}$. Marine invasions in this area began in the upper Permian and continued with recessions through the Triassic. Progress of the rift was slow until the beginning of the Cretaceous and then proceeded rapidly southwards along the North American coast.

The African province drifted towards Atlantica and probably made contact with south-east Atlantica during the Jurassic. Faulting along the line of separation between Africa and South America must have then been far advanced, as the separation followed rapidly on that of Europe and North America and was completed early in the Cretaceous. It is probable, therefore, that Africa was in contact with Atlantica for a large part of the Jurassic, time enough for a considerable migration of angiosperms before the Atlantic Ocean developed.

The faulting which heralded the break-up of Pacificathe rift valley phase-was probably well advanced by the late Triassic. It was accompanied by metamorphosism in the Japanese region and followed by a second phase of metamorphosism in the late Cretaceous ${ }^{19 e}$, which must have marked the final stages of the drift. The uprising convection current under the continent raised the land surface $2-3 \mathrm{~km}$ along the line of the Darwin Rise. At the southern end this caused the formation of a land-bridge between Pacifica and the New Zealand block, linking the regions now forming New Guinea, New Caledonia and the western fragments of South America which then formed part of the southern Pacific land mass. This land bridge must have formed early enough to allow a few representatives of the Glossopteris flora to reach Kansu in the Triassic'. It was the major link between Gondwanaland and the northern continent and accounts for the high concentration of relatively primitive angiosperms which still survive in southeast Asia and New Guinea and New Caledonia. Contact between north and south continued longer before the drift started than that between Africa and Atlantica, but the onset of drift was probably early in the Cretaceous to account for sedimentation in the Pacific basin and the ages of atolls and guyots reported by Menard ${ }^{20}$.

The next phase in the disruption of Gondwanaland was the development of the mid-Indian rise which continued south-eastwards through the junction between Australia and Antarctica. Evidence to date the northward drift of India is scanty, but it may have started in the mid-Cretaceous, and contact was made with the Angara-Cathaysia block by the Palaeocene, though folding of the Himalaya continued into the Oligocene $e^{19 h}$. The drift of India was relatively rapid and, in its passage north, the resulting climatic changes caused the almost complete annihilation of its rich gymno. sperm flora ${ }^{16}$. Perhaps for the same reason, India appears to have made a smaller contribution to modern floras than its size would warrant.

Concurrently with the drift of India, Australia was pushed eastwards along the line of the Diamantina fracture zone ${ }^{19 i}$. The centre of activity moved eastwards along the Indian-Antarctic rise, driving eastern Australia northwards late in

Africa and South America began to drift away from the remainder of Gondwanaland in the upper Permian according to palaeomagnetic evidence ${ }^{10}$. Assuming this date to be accurate, the general trends of evolution in the angiosperms must have been determined by this time although their fertilization mechanism may still have been gymnospermous. Progenitors of such families as Proteaceae, Leguminosae and Restionaceae must have been dispersed through both African and Australian provinces of Gondwanaland to account for their modern distribution. the Cretaceous. The combined movements caused the rotation of Australia, bringing it into contact with New Guinea which, by this time, had drifted to the south-east of its present position. New Guinea was forced northwards and the adjacent island ares were curved into their present positions. The rift continued eastwards along the line of the Pacific-Antarctic Rise and then north-eastward along the East Pacific Rise, separating the New Zealand block from Western Antarctica and from the Chilean and Peruvian fragments of South 
America at the end of the Cretaceous or Palaeocene. The final stages of the movement caused the raising of the Andes in the Miocene.

Before the break-up of Gondwanaland, continuous land connexion existed between India, Antarctica and eastern Australia (Fig. 3). With the development of the East Pacific Rise, the gap between Australia and New Zealand across the Ross Sea area must have been bridged. It is evident that during the Cretaceous the circumAntaretic land bridge postulated by plant geographers from Hooker ${ }^{26}$ to van Steenis ${ }^{27}$ actually existed. The reason for such sub-Antaretic distributions as that of Juncus scheuchzerioides in Kerguelen, Tasmania, New Zealand, Fuegia and the Falklands is now clear. The separation of the New Zealand block from the Chilean fragments of South America was late enough to account for the identity of the small number of Hebe species in the latter area with their New Zealand congeners. The genus Nothofagus, at present with a disjunct distribution in Tasmania, Eastern Australia, New Guinea, New Caledonia, New Zealand, Chile and Western Antarctica (fossil), in the Cretaceous occupied a single land area. Coriaria, now inhabiting New Zealand, South America and China with one species in Europe, was able to migrate from its Gondwanic home to China in the early Cretaceous, and, after drift, across to Europe. Pleistocene glaciation probably accounts for its absence now in the rest of temperate Asia. The links between the floras of Japan and South America discussed by Maekawa ${ }^{28}$ can be explained on the basis of pre-existing land connexions. So also can other distributions mentioned by Camp 4 , and it may be found profitable to compare the maps published by Vester ${ }^{29}$ with the disposition of land in the Jurassic and Cretaceous as revealed by the present synthesis.

Although parts of these reconstructions may appear to be somewhat speculative, every position mapped rests on evidence from two or more disciplines. It is hoped that the attention drawn to gaps in our knowledge will lead to further research on related problems. I am grateful to Dr. E. P. Plumstead for discussing the distribution of the Glossopteris flora and to colleagues at Kew and the British Museum for their interest and encouragement.

${ }^{1}$ Hawkes, J. G., and Smith, P., Nature, 207, 48 (1965).

2 Stebbins, G. L., Variation and Evolution in Plants (Columbia Univ. Press, 1950).

Thomas, H. H., Bot. Rev., 2, 397 (1936).

- Camp, W. H., Ecol. Mon., 17, 161 (1947).

- Plumstead, E. P., Trans-Antarctic Exped. 1955-58. Sci. Rep., 9 (1962).

' Melville, R., Nature, 188, 14 (1960).

'Melville, R., Kew Bull., 16, 1 (1962).

${ }^{8}$ Melville, R., Kew Bull., 17, 1 (1963).

' Seward, A., Plant Life Through the Ages (Cambridge, 1931).

${ }^{10}$ Creer, K. M., Nature, 203, 1115 (1964).

11 Sherlock, R. L., Geol. Mag., 71, 112 (1934).

${ }^{12}$ Krause, D. C., Science, 146, 57 (1964).

${ }^{13}$ Sahni, B., J. Ind. Bot. Soc., 15, 319 (1936).

14 Salim Ali, in New Dictionary of Birds, edit. by Thompson, A. L., 557 (Neison, London, 1964).

${ }^{15}$ Good, R., Tenth Pacif. Sci. Congr., 301 (1961).

is Florin, R., Act. Hort. Berg., 20, 121 (1961).

${ }^{17}$ King, L., and Downard, T. W., Antaretic Geology, edit. by Adie, R. J., 730 (North Holland Pub. Co., Amsterdam, 1964).

${ }^{18}$ Ahmad, F., Nature, 210, 81 (1966).

${ }^{18}$ A Symposium on Continental Drift. Phil. Trans. Roy. Soc., No. 1088 (1965).

(a) Bullard, ti., Everett, J. E., and Smith, A. G., Fig. 8;

(c) Runcorn, s. K., 1-11;

(d) Fitch, F. J., 191-3;

(e) Sutton, J., 107

(f) Girdler, ... W., 127;

(g) Westol, T. S., 22 ;

h) Harland, W. B., 211

(i) Heezen, B. C., and Tharp, M., 100.

${ }^{20}$ Menard, H. W., Marine Geology of the Pacitic (McGraw-Hill, 1964).

${ }^{21}$ Irving, E., and Green, R., Nature, 179, 1064 (1957).

${ }_{22}$ Holmes, A., Principles of Physical Geology, 501 (Nelson, London, 1944). ${ }^{23}$ Schuchert, C., Atlas of Palaegeographic Maps of North America (Wiley,

${ }_{24}$ Deutsch, E. R., and Watkins, N. D., Nature, 189, 543 (1961).

${ }^{25}$ Stose, G. W., Geologic Map of South America (Geol. Soc. Amer., 1950).

${ }^{28}$ Hooker, J. D., Phil. Trans. Roy. Soc., 168, 2 (1879).

${ }^{27}$ Steenis, C. G. G. J. van, Blumea, 11, 235 (1962).

${ }^{28}$ Maekawa, F., J. Sci. Univ. Tokyo, 9, 161 (1965).

${ }^{2}$ Vester, H., Bot. Archiv., 41, 202, 275 (1940).

\section{BOOK REVIEWS}

\section{UNBRIDLED RACISM}

\section{Racial Contours}

The Factor of Race in Human Survival. By H. B. Isherwood. Pp. 423. (Douglas, Isle of Man: Times Press, Ltd., 1965.) $18 s$.

REAdING this book is a disheartening experience. It is scarcely credible that such congeries of misrepresentation, warped judgment, and just plain gibberish can be pub. lished in the Age of Science, and in Great Britain rather than in some underdeveloped country. Here are some samples: ". . . we have no alternative but to assume that from the statistical analysis there are fewer genes (or less complex gene combinations) in the lower primates than in, say, the Australoids, even though they may have the same number of chromosomes, that also there are fewer genes in the lowly Australoid than in, say, the Negroid, and that there are fewer genes in the Negroid than in the Mongoloid". The blue-blooded Nordies must be brimming with genes. This does not make them safe from dangers, because "Hybrids do not breed true and by miscegenatic multiplication inferior variants would be thrown off and the superior race as a biological entity would lose its place in the evolutionary scramble. In short, exogamy indulged in by a more advanced people inevitably tends to impair the intrinsic quality of that people. About this there can be no dispute". These, and many other equally "indisputable" facts, are the basis of many pages of unbridled racism. Pages 148-178 are an antisemitic tract, complete with the story, "believed by the learned as well as the ignorant", that Jews used the blood of children of other races in their paschal celebrations, and the Protocols of the Learned Elders of Zion. The political conflicts and the Cold War are explained very simply: "Americans believe themselves to be in direct ideological opposition to the U.S.S.R. The impossibility of reconciliation between these two great Caucasoid powers arises from roots deeper than ideas or social forms. Large percentages of the peoples of both countries are non-Caucasoid and the racial ratio will change in each country, coloring the collective character and ethos of the populations. In this respect the evolutionary advantage undoubtedly lies with the U.S.S.R. Yet both powers, indeed the whole Caucasoid race, may in the end be beaten in the struggle to survive by the more stable and homogeneous Mongoloids". There is not even hope that the Caucasoid thoroughbreds can be preserved by emigration: "Despite the rapid progress now being made in cosmic rocketry the feasibility of transporting men in effective numbers to another planet or star could be ruled out as not being realizable in time". Here one is tempted to conclude-if mankind really is what the author says it is - that other planets ought not to be contaminated by it. Theodosius Dobzhansky

\section{WORKING ON ANIMALS}

\section{Methods of Animal Experimentation}

Edited by William I. Gay. Vol. 1, pp. xv+382. 96s. 6d. Vol. 2, pp. $\mathrm{xv}+608$. 148s. (Now York: Academic Press, Inc.; London: Academic Press, Inc. (London), Ltd., 1965.)

DR. GAY is to be congratulated on undertaking a task of considerable magnitude, knowing well that it would be impossible to achieve perfection at the first attempt. As chief of the Animal Resources Branch, Division of Research Facilities and Resources of the U.S. National Institutes of Health, he is in a particularly good position 